\title{
ANALISIS KEBUTUHAN BAHASA JEPANG DAN BAHASA PRANCIS OLEH MAHASISWA PROGRAM STUDI SASTRA INGGRIS UNIVERSITAS UDAYANA
}

\author{
IGAG Sosiowati, Putu Weddha Savitri, Putu Lirishati Soethama \\ Fakultas Ilmu Budaya, Unud \\ gag_sosiowati@unud.ac.id,weddha_savitri@unud.ac.id,lirishati_soethama@unud.ac.id
}

\begin{abstract}
Abstrak
Penelitian ini bertujuan untuk mengetahui apa yang sesungguhnya dibutuhkan oleh mahasiswa Prodi Sastra Inggris dari pembelajaran Mata Kuliah Bahasa Asing Pilihan (MK BAP) yaitu Bahasa Prancis dan Bahasa Jepang. Agar pembelajaran MK BAP dapat berjalan efektif dan efisien maka dibutuhkan rencana pembelajaran yang tepat. Oleh karena itu analisis kebutuhan sangat penting untuk dilakukan sehingga pengajar dapat menentukan materi, metode pengajaran, maupun buku referensi yang tepat dan dapat menjawab kebutuhan mahasiswa.

Populasi penelitian ini adalah mahasiswa Prodi Sastra Inggris yang telah menyelesaikan MK Bahasa Prancis dan Bahasa Jepang. Metode survey, kuisioner dan wawancara digunakan untuk mendapatkan data mengenai kebutuhan mahasiswa terhadap MK BAP yang mengacu pada Target Needs dan Learning Needs dari Hutchinson and Waters (1987). Analisis data dilakukan dengan tekhnik deskriptif kualitatif untuk mendapatkan hasil penelitian berupa kebutuhan mahasiswa terhadap Bahasa Prancis dan Bahasa Jepang.

Hasil penelitian menunjukkan bahwa mahasiswa lebih membutuhkan kemampuan berbicara, dengan materi mengenai ungkapan yang umum digunakan, dan topic-topik yang berkaitan dengan kegiatan sehari-hari seperti berbelanja, memesan makanan, berbicara tentang hobby, teman, wisata dan kegiatan lainnya.
\end{abstract}

Kata kunci: analisis kebutuhan, bahasa prancis, bahasa jepang

\section{PENDAhuluan}

Pada era digital dan globalisasi ini, jarak tidak lagi menjadi suatu masalah dalam berkomunikasi. Setiap orang dapat berkomunikasi dengan orang dari belahan dunia lain melalui berbagai media komunikasi yang berkembang dengan sangat pesat. Dalam berkomunikasi tentu saja dibutuhkan suatu bahasa. Seperti yang telah diketahui, Bahasa Inggris merupakan bahasa internasional pertama yang harus dikuasai untuk memudahkan komunikasi antar bangsa. Namun seiring dengan perkembangan jaman, bahasa asing lain juga mulai digunakan dalam berbagai event international, seperti bahasa Prancis, China, Spanyol, Jepang, dan lain-lain. Oleh karena itu, semua orang berlomba-lomba mempelajari dan menguasai bahasa asing lainnya selain bahasa Inggris, dengan berbagai tujuan antara lain untuk tujuan ekonomi, komunikasi lintas budaya, travelling, pekerjaan, bahkan untuk alasan prestige.

Berdasarkan fenomena tersebut, program studi Sastra Ingris mencantumkan bahasa asing pilihan ke dalam kurikulumnya. Mahasiswa Prodi Sastra Inggris diharuskan memilih bahasa Jepang atau Bahasa Prancis selama 2 Semester (4SKS). Dengan minimnya alokasi waktu yang ada, maka akan cukup sulit memberikan kemampuan bahasa Prancis 
atau Bahasa Jepang yang lengkap. Berdasarkan pengamatan pengajar MK BAP, mahasiswa memiliki minat yang cukup baik, namun karena frekuensi pertemuan yang hanya 16 kali pertemuan per semester, ditengarai bahawa mahasiswa belum dapat menguasai dengan baik materi dasar yang diberikan. Oleh karena itu, agar pengajaran bahasa asing tersebut dapat berlangsung efektif dan efisien, maka diperlukan adanya analisa kebutuhan yang dapat menjawab apa saja kebutuhan mahasiswa dari MK Bahasa Prancis dan Jepang, sehingga kedepannya pengajar dapat membuat rencana pembelajaran yang sesuai dengan kebutuhan mahasiswa. Selain itu, pengajaran MK BAP juga dapat memberikan kemampuan tambahan kepada mahasiswa untuk masuk ke dalam dunia kerja.

Kesesuaian materi pembelajaran dan kebutuhan mahasiswa dalam berbahasa Asing Pilihan merupakan salah satu hal penting yang harus diperhatikan oleh pengampu mata kuliah. Salah satu asumsi dasar pengembangan kurikulum atau rencana pembelajaran adalah harus didasarkan pada analisa kebutuhan pembelajar. Selain itu, keberhasilan pengajaran Bahasa Prancis dan Bahasa Jepang juga tergantung dari minat mahasiswa terhadap bahasa asing pilihannya. Untuk itu, penelusuran minat mahasiswa perlu juga dilakukan untuk mengetahui kekuatan dan kelemahan mahasiswa.

\section{TEORI DAN METODE}

\subsection{Needs Analysis}

Analisis kebutuhan adalah prosedur yang dilakukan untuk mengumpulkan informasi mengetahui kebutuhan peserta didik (Purnama, 2013). Sedangkan tujuan diadakannya analisis kebutuhan adalah untuk mengetahui materi yang diperlukan oleh peserta didik, metode pengajaran yang diinginkan, membantu menentukan program yang dapat menunjang kemampuan peserta didik, dan mencari informasi mengenai kesulitan yang dihadapi maupun kapasitas mahasiswa dalam memahami materi yang diberikan.

Istilah kebutuhan tidak selalu tertuju pada halhal yang kelihatan, dan istilah ini kadang-kadang digunakan untuk merujuk kepada kemauan, permintaan, harapan, motivasi, keperluan, larangan, dan kewajiban (Brindley 1984, 28). Analisis kebutuhan biasanya dilakukan oleh pengajar untuk mendapatkan informasi mengenai kebutuhan peserta didik sehingga pengajar dapat memetakan kebutuhan dan target yang ingin dicapai, sehingga pembelajaran dapat berlangsung dengan efektif dan efisien.

Target populasi dari suatu analisis kebutuhan adalah orang-orang yang memiliki informasi yang dibutuhkan. Biasanya dalam kelas bahasa, akan ditemukan orang-orang yang potensial ataupun yang kurang berminat yang dapat memberikan informasi mengenai kebutuhan mereka.

\subsection{Teori dan Metode Penelitian}

Analisa kebutuhan mencakup 2 hal yaitu target needs dan learning needs Hutchinson and Waters (1987). Target kebutuhan mencakup necessities (kebutuhan), Lacks (kekurangan) dan wants (keinginan). Ketiga hal ini merupakan komponen yang sangat penting untuk mengetahui apa yang pembelajar harus tahu agar dapat berfungsi secara efektif sesuai dengan sasaran. Target situasi juga perlu untuk dilakukan untuk mengetahui target dan sikap peserta dalam proses pembelajaran. Sedangkan Learning needs atau kebutuhan pembelajaran adalah menyangkut situasi pembelajaran yang dapat menyenangkan dan memuaskan pembelajar.

Berbagai prosedur dapat digunakan dalam melakukan analisis kebutuhan dan jenis informasi yang diperoleh seringkali tergantung pada prosedur yang dipilih. Apabila salah satu sumber informasi mungkin tidak lengkap atau parsial, pendekatan segitiga (yaitu, mengumpulkan informasi dari dua atau lebih sumber) yang dianjurkan. Prosedur untuk mengumpulkan informasi selama analisis kebutuhan antara lain melalui kuisioner, wawancara, diskusi, observasi, analisis tugas, mengumpulkan sampel pembelajar, serta studi kasus. Dalam penelitian ini, metode pengumpulan data yang digunakan adalah melalui kuisioner, wawancara, dan observasi. Hasil analisis diasampaiakn secara kuantitatif dan kualitatif. 


\section{PEMBAHASAN}

Mahasiswa sastra Inggris semester 2 (120 orang) merupakan objek dari penelitian ini, karena mereka dianggap representative dalam memberikan data mengenai apa yang menjadi kebutuhan mahasiswa terhadapa mata kuliah bahasa asing pilihan yaitu bahasa Prancis dan Bahasa Jepang. Sebanyak 73 orang mahasiswa memilih bahasa Prancis, dan sisanya 52 orang memilih Bahasa Jepang. Berikut akan dipaparkan analisis kebutuhan mahasiswa Prodi Sastra Inggris terhadapa kedua bahasa asing pilihan tersebut.

\section{Target Needs}

Dalam analisis target needs akan difokuskan pada 3 hal yaitu Lacks (kekurangan), wants (keinginan), dan needs (kebutuhan) dari pembelajar.

\section{a. Lacks (kekurangan)}

Pada bagian ini kekurangan dan kelebihan pembelajar akan ditelaah sehingga akan didapatkan gambaran umum tentang latar belakang, motivasi dan sikap pembelajar, termasuk didalamnya minat mahasiswa terhadap bahasa pilihannya. Informasi mengenai hal ini dapat dijadikan pertimbangan penting dalam menentukan arah pembelajaran.

\section{- Latar Belakang}

Latar belakang yang dimaksud disini adalah apakah sebelumnya mahasiswa pernah mempelajari bahasa asing pilihannya atau tidak. Hal ini bertujuan untuk memetakan persentase pembelajar yang potensial dan telah memiliki pengetahuan dasar. Berdasarkan hasil dari kuisioner, didapatkan informasi bahwa hampir 75\% mahasiswa yang memilih bahasa Prancis belum pernah mempelajarinya baik secara formal maupun informal, sedangkan 25\% lainnya menyatakan pernah mempelajari bahasa Prancis ketika berada di Sekolah Menegah Atas dan beberapa orang pernah mengikuti kursus bahasa Prancis. Hal ini dapat dikatakan kekurangan (lacks) karena mahasiswa yang memilih bahasa Prancis harus belajar lebih keras karena minimnya pengteahuan mereka tentang bahasa Prancis. Hal yang sebalikanya didapat dari kelompok mahasiswa yang memilih bahasa Jepang, yaitu $65 \%$ menyatakan pernah mempelajari bahasa Jepang, dan 35\% menyatakan belum pernah. Dari hasil ini dapat disimpulkan bahwa bahasa Jepang sudah cukup familiar sehingga potensi kemampuan mahasiswa yang memilih bahasa Jepang mungkin lebih tinggi dari potensi mahasiswa yang memilih bahasa Prancis. Hal ini dapat menjadi pertimbangan dalam memberikan materi awal pembelajaran yang harus diberikan.

Tabel 1. Latar belakang pembelajar

\begin{tabular}{|l|c|c|}
\hline & Pernah belajar & Belum pernah \\
\hline Bahasa Prancis & $25 \%$ & $75 \%$ \\
\hline Bahasa Jepang & $65 \%$ & $35 \%$ \\
\hline
\end{tabular}

- Motivasi dan minat

Mengetahui motivasi dan minat mahasiswa dalam menentukan pilihan bahasa asing menjadi salah satu pertimbangan untuk menentukan karakter pembelajar, apakah mereka akan bersungguh-sungguh dalam belajar Bahasa Asing pilihannya atau tidak. Melalui kuisioner dan wawancara, didapatkan beberapa motivasi mahasiswa kenapa memilih Bahasa Prancis atau Bahasa Jepang, antara lain menambah kemampuan Bahasa Internasional selain bahasa Inggris, memperluas wawasan dan komunikasi, untuk hal pendidikan (melanjutkan studi), bekal dimasa depan dan untuk travelling. Dilihat dari motivasi yang disampaikan oleh mahasiswa, belum tampak adanya kebutuhan yang mendesak yang menuntut mereka untuk menguasai bahasa Prancis atau Bahasa Jepang dengan baik, sehingga dapat dikatakan tingkat keseriusan mereka dalam mempelajari kedua bahasa asing tersebut masih belum maksimal.

Hal ini juga selaras dengan hasil penelusuran minat mahasiswa terhadap Bahasa Prancis dan Bahasa Jepang yaitu kurang dari 50\% 
populasi kelas yang menyatakan mempunyai minat yang tinggi terhadap kedua bahasa tersebut. Hal ini tentu saja dapat dimaklumi karena populasi merupakan mahasiswa Program Studi Bahasa Inggris yang tentu saja tujuan utama mereka adalah menguasai Bahasa Inggris dengan baik.

\section{- Sikap}

Sikap mahasiswa ketika mengikuti proses pembelajaran MK BAP adalah sebagai berikut: sebagian besar menyatakan menyimak dan menikmati pembelajaran (55\%) namun keaktifannya masih sangat kurang baik ketika di dalam kelas maupun belajar secara mandiri. Sedangkan jika dilihat dari pandangan mereka terhadap Bahasa Prancis dan Bahasa Jepang, hampir semua mahasiswa menyadari betapa pentingnya menguasai bahasa asing lainnya selain bahasa Inggris untuk memperluas wawasan ataupun sebagai penunjang dalam dunia kerja. Namun hal ini tidak cukup membuat mahasiswa mempunyai keinginan untuk lebih memperdalam lagi bahasa Prancis maupun Bahasa Jepang secara mandiri di luar perkuliahan (jika biaya dan waktu memungkinkan). Hanya $38 \%$ populasi yang berkeinginan untuk melanjutkan pembelajaran BP dan BJ diluar perkuliahan Jadi disini peran pengajar juga harus dapat menggugah minat mahasiswa terhadap BP dan BJ, serta berupaya merevisi metode ataupun materi yang akan diberikan agar minat mahasiswa dapat lebih ditingkatkan.

Tabel 2. Sikap pembelajar terhadap Bahasa Prancis dan Bahasa Jepang

\begin{tabular}{|l|c|c|c|}
\hline & $\begin{array}{c}\text { Sangat } \\
\text { penting }\end{array}$ & Penting & $\begin{array}{c}\text { tidak } \\
\text { penting }\end{array}$ \\
\hline Bahasa Prancis & $19 \%$ & $78 \%$ & $3 \%$ \\
\hline Bahasa Jepang & $18 \%$ & $74 \%$ & $5 \%$ \\
\hline
\end{tabular}

\section{b. Wants (keinginan)}

Sebagian besar mahasiswa ingin menguasai Bahasa Prancis maupun Bahasa Jepang dengan baik pada semua skill yaitu membaca, mendengar, menulis dan berbicara, sekaligus dapat pula memahami tata bahasa dan pengucapan yang baik dan benar dari bahasa yang dipelajarinya.

\section{c. Needs (Kebutuhan)}

Hasil dari kuisioner memperlihatkan bahwa mahasiswa Program Studi Sastra Inggris membutuhkan materi tentang percakapan sehari-hari karena dianggap materi tersebut dapat diaplikasikan langsung ketika berkomunikasi. Hal ini sejalan dengan pendapat mereka tentang manfaat menguasai bahasa asing selain bahasa Inggris yaitu untuk memperluas wawasan dalam hal ini dapat berkomunikasi dengan orang yang menggunakan bahasa asing tersebut. Sedangkan kegunaan bahasa asing untuk dapat menunjang kesempatan bekerja yang lebih baik, tidak menjadi prioritas utama mereka. Materi tentang tata bahasa menempati kebutuhan berikutnya agar dapat menguasai lebih lanjut BP maupun BJ. Sedangkan materi tentang tujuan khusus (perhotelan, retauran, travel agent, dll) masih belum mereka perlukan karena mereka menyadari bahwa materi tersebut membutuhkan penguasaan BP atau BJ yang lebih tinggi.

Tabel 3. Kebutuhan mahasiswa akan materi pembelajaran BP dan BJ

\begin{tabular}{|l|c|c|c|}
\hline & $\begin{array}{c}\text { Tata } \\
\text { Bahasa }\end{array}$ & $\begin{array}{c}\text { Percaka- } \\
\text { pan se- } \\
\text { hari-hari }\end{array}$ & $\begin{array}{c}\text { Bahasa } \\
\text { asing tujuan } \\
\text { khusus }\end{array}$ \\
\hline Bahasa Prancis & 24org & 5 oorg & 9org \\
\hline Bahasa Jepang & 18org & 36 org & 8org \\
\hline
\end{tabular}

\section{Learning Needs}

Learning needs atau kebutuhan pembelajaran adalah menyangkut situasi pembelajaran yang dapat menyenangkan dan memuaskan pembelajar. Berdasarkan hasil kuisioner, pembelajar menginginkan beberapa hal tentang MK BAP sebagai berikut:

- Waktu pembelajaran agar dapat ditambah karena dengan 4 SKS dirasakan masih kurang untuk dapat menguasai Bahasa 
Prancis ataupun Bahasa Jepang.

- Fasilitas yang lebih lengkap seperti alat audio visual dengan standar yang bagus, lab bahasa, kecepatan akses internet, ruang kelas yang nyaman, dan lain-lain

- Jumlah siswa dalam satu kelas tidak terlalu banyak sehingga proses pembelajaran dapat berlangsung dengan efektif dan setiap orang mendapatkan kesempatan untuk berlatih percakapan.

- Materi yang lebih menarik dan metode pembelajaran yang atraktif sehingga mahasiswa tidak bosan dan bisa lebih aktif.

Berdasarkan analisa kebutuhan diatas, beberapa poin penting dapat dijadikan acuan untuk perbaikan rencana pembelajaran MK Bahasa Asing Pilihan kedepannya. Sikap positif yang ditunjukkan oleh mahasiswa terhadap Bahasa Prancis dan Bahasa Jepang dapat menjadi modal yang cukup baik untuk dapat meningkatkan kemampuan mahasiswa dalam penguasaan materi yang diajarkan, sehingga capaian pembelajaran dapat tercapai. Peningkatan kemampuan berbicara menjadi poin yang harus diperhatikan dengan pemberian materi tentang percakapan seharihari yang tentunya didukung oleh sasilitas yang memadai.

\section{KESIMPULAN}

Berdasarkan analisa yang telah dilakukan, dapat disimpulkan bahwa mahasiswa Program Studi Sastra Inggris sangat menyadari pentingnya menguasai Bahasa asing lain selain bahasa Inggris, sehingga mereka pun menyikapi MKBahasa Prancis dan Bahasa Jepang dengan positif. Namun motivasi mereka belum cukup kuat untuk dapat menguasai kedua bahasa tersebut sehingga dari keseluruhan populasi hanya $38 \%$ yang menyatakan berniat melanjutkan mempelajari bahasa pilihannya tersebut diluar kampus. Dari segi kemampuan, mahasiswa ingin memiliki kemampuan berbicara dengan menggunakan bahasa asing tersebut sehingga mereka menyatakan lebih membutuhkan materi atau topik percakapan mengenai kehidupan sehari-hari seperti mengucapkan salam, perkenalan, dalam situasi berbelanja, bertanya untuk mendapatkan informasi, mengungkapkan waktu, kesukaan, dan lain-lain. Sedangkan kendala yang ditemukan dalam pembelajaran bahasa pilihan adah rasa kurang percaya diri mahasiswa serta jumlah mahasiswa yang cukup besar dalam satu kelas sehingga proses pembelajaran menjadi kurang maksimal. Selain itu, mahasiswa juga membutuhkan beberapa pemenuhan fasilitas belajar yang baik dan dapat menunjang proses pembelajaran bahasa asing.

\section{DAFTAR PUSTAKA}

Harmer, Jeremy. 1983. The Practice of English Language Teaching. London and New York: Longman

Harmer, Jeremy. 2005. The Practice of English Language Teaching (Third Edition.completely revised and edited) London and New York: Longman

Hutchinson, Tom and Waters, Alan. 1994. English for Specific Purposes. Glasgow: Bell \& Bain Ltd.

Mahsun. 2007. Metode Penelitian Bahasa (Edisi Revisi). Jakarta: PT. Rajagrafindo Persada

Masduki. 2004. "Studi Kemampuan Berbahasa Inggris Mahasiswa Non-English Department" Melalui Kegiatan Intensive Course Model B'

Purnama, Asri. 2013. Needs Analysis. Available at http://asripurnama1o.blogspot.co.id/2013/ 05/needs-analysis-analisis-kebutuhan.html, cited on 25 Januari 2017

Sukarni, Sri. 2016. Analisis Kebutuhan Bahasa Inggris Mahasiswa Universitas Nusa Tenggara Barat. Jurnal Media Bina Ilmiah Vol. 10, No.1. ISSN No. 1978-3787. 